\title{
Narcismus ve výchově a vzdělání
}

\author{
Michal Podzimek \\ Technická univerzita v Liberci, Fakulta přírodovědně-humanitní a pedagogická, \\ Katedra filosofie
}

Redakci zasláno 5. 7. 2017 / upravená verze obdržena 5. 10.2017 /

k uveřejnění přijato 15. 10. 2017

\begin{abstract}
Abstrakt: $V$ důsledku procesu individualizace se postmoderní společnost stala svědkem významného hodnotového posunu. Tradiční koncepce vzdělávání se v tomto smyslu také jeví jakožto problematická. Škola se stala jednou z nejdůležitějších sociálních institucí, ve které tráví žák svůj čas v roli obsluhovaného klienta, uspokojovaného $\mathrm{v}$ jeho potřebách. Tento druh vztahu podporuje fenomén narcismu, který deformuje postoj k vnějšímu světu. Vybrané studie americké provenience ukazují pedagogický pohled na narcistický fenomén jako na nový trend, protože kulturní narcismus je součástí současné transformace západní společnosti a v budoucnu se může stát i fenoménem globálním. Studie se snaží podpořit promýšlení realizace dalších pedagogických výzkumů vzdělávání, které jsou na evropské úrovni velmi potřebné.
\end{abstract}

Klíčová slova: narcismus, individualismus, patologie, porucha učení, pedagogický výzkum

Každá doba má svoji specifickou formu patologie (Lasch, 2016, s. 10), napsal dnes již dávno zesnulý prof. Christopher Lasch, a za tuto patologii označil problém narcismu jakožto zahledění se do sebe na způsob mytologického Narcise. Profesor Lasch byl tak prvním, který se pokusil toto téma uchopit jako sociální fenomén a popsat jej z historicko-antropologického pohledu uceleně. Poprvé toto téma otevřel již v roce 1976 Tom Wolfe ve slavném novinovém článku The me decade and the third great awakening, tedy Moje desetiletí a třetí velké probuzení (Wolfe, 1976). Souvisle pak o narcismu jako o jednom z projevů současné kultury pojednal právě Lasch ve své slavné knize $\mathrm{z}$ roku $1980 \mathrm{~s}$ názvem The culture of narcissism, Kultura narcismu. Je alarmující, že tato publikace, obsahem důležitá nejen pro sociologii, ale také pro pedagogickou perspektivu, byla přeložena do českého jazyka teprve $\mathrm{v}$ roce 2016. Narcismus byl v tomto díle poprvé uchopen ne pouze jako strukturální porucha osobnosti v psychopatologickém smyslu slova, ale byl představen jako charakteristický životní styl současné hypermoderní doby 
(Lipovetsky, 2013). Populárně-naučně se věnuje tématu narcismu především Gilles Lipovetsky. Ten již ve své první velké monografii Éra prázdnoty z roku 1983 napsal, že procesem personalizace se individualismus mění v to, co po vzoru americké sociologie nazýváme kulturním narcismem (Lipovetsky, 1998, s. 16).

Téma kulturního narcismu se tedy stalo naléhavým především $\mathrm{v}$ posledních dvou desetiletích u tzv. Me, me, me generation (Generace Y), vyrostlé v posledních dvou dekádách 20. století, a u generace jejich dětí. Jelikož je ohrožení kulturním narcismem vzrůstajícím celospolečenským fenoménem, musí se o tuto formu životního stylu začít zajímat i ti, kteří mají odpovědnost za vzdělávání a výchovu. Protože narcismus jakožto životní styl a narcistické excesivní chování ve smyslu psychické poruchy se navzájem nevylučují, ale naopak se prolínají a prostupují životní pohyb člověka, je třeba k tomuto tématu přistupovat nejen z psychologické, ale také z pedagogické strany, v pedagogických studiích a výzkumech tohoto typu. Jak bude ukázáno dále, jedná se zatím o jakési „neorané pole“, a to jak v sociologickém, tak především v pedagogickém výzkumu. Lze však již pozorovat i „první vlaštovky“, a to především ve výzkumech realizovaných vysokoškolskými pedagogy a psychology v USA v první dekádě po miléniu. A právě o tyto výzkumy, jakkoliv jsou zatím stále nemnohé, se opírá i tato studie.

\section{Vymezení narcismu}

Celý koncept fenoménu narcismu vyrostl přirozeně z psychologie, respektive z prostředí freudovské psychoanalýzy. Narcismus byl tak poprvé definován jako patologie, konkrétně psychologická porucha hédonistů. Jakkoliv jsou následující informace u odborné veřejnosti obecně známé, je třeba je zde krátce připomenout, aby bylo zřejmé, že fenomén narcismu nemusí být vždy patologický. Již samotný Sigmund Freud odlišil dva typy narcismu: první patří $\mathrm{k}$ přirozenému vývoji dítěte, které se v raném stádium vývoje své osobnosti musí umět vyrovnat vedle hysterie i s problémem sebestřednosti. Teprve pokud se s tímto problémem nevypořádá nejpozději do třetího roku svého života, lze hovořit o jakémsi druhém narcismu jakožto patologii. Jinak řečeno, $\mathrm{k}$ přirozenosti vývoje patří, aby byl každý člověk ve svém raném dětství přesvědčen o své vlastní všemohoucnosti. Aby však tyto postoje nepřešly do excesivní, a tedy patologické formy, musí toto přesvědčení postupně ztrácet zjišt’ováním, že objekty jeho narcismu nejsou závislé na něm, ale 
právě naopak. Freud pak také upozorňuje, že i když se s výše uvedenými fakty života vyrovnáme $v$ dětství normálně, do jisté míry vždy trochu zůstáváme narcisem i v dospělosti. Tento přirozený narcismus pak evokuje lidskou vůli k tomu, naučit se se sebestředností zacházet (Freud, 1997).

Podobně jako Sigmund Freud i Erich Fromm užívá termín narcismus pro tzv. asociální individualismus. Také on zohledňuje skutečnost, že narcismus má svoji důležitou sociálně-biologickou funkci u celé duševně zdravé populace tím, že zajišttuje naplňování tužeb jedinců a paradoxně pomáhá rozvíjet vztahy soutěživostí. Proto je narcismus pro kvalitu a někdy i samotné uchování života nezbytný. Zároveň je však i nebezpečný, pokud přeroste do patologické formy (Fromm, 1996). Fromm neváhá při historické analýze některých osobností minulosti tvrdit, že jejich excesivní jednání bylo důsledkem silného vlivu patologického narcismu: Stalin, Hitler, Caligula a jiní léčili svůj narcismus tím, že přetvářeli svět tak, aby odpovídal jejich představám (Fromm, 1996, s. 86).

Co je však oproti Freudově psychoanalýze v současném pohledu na narcismus nové, je jeho vnímání jakožto skupinového fenoménu - tzv. kulturního narcismu. Pokud totiž v době Freuda byl patologický narcismus fenoménem pouze minoritních bohatých vrstev obyvatelstva, dnes je prostoupen prakticky celou majoritou. Pro jeho naplnění dává konzumní společnost nejen jednotlivci, ale i skupinám možnost: „poskytnout narcistické uspokojení zhoubného typu, chceme-li zabránit tomu, aby vznikla nespokojenost. Pro ty, kdo jsou ekonomicky i kulturně chudí, je jediným zdrojem zadostiučinění - a často velice účinným - jejich narcistická pýcha, že patří ke skupině." (Fromm, 1996, s. 89).

Jinak řečeno, starořímské heslo panis et ludes (chléb a hry) je nově aktuální a patří k předním fenoménům konzumní společnosti.

Oblast kulturního narcismu, jak ji vnímá Erich Fromm či Zygmund Bauman a jim podobní myslitelé, jako byl Heinz Kohut, Otto Kernberg či Irvin Yalom, komplexně pojal již výše uvedený prof. Lasch, když v úvodu své knihy popsal jakési hlavní charakteristiky narcistní společnosti. Jsou jimi:

- všeobecná ztráta historické kontinuity (lhostejnost k minulosti i budoucnosti);

- závislost na byrokracii; 
- neschopnost empatie;

- pokles institucionální autority;

- př́lišné zaujetí psychoterapií;

- sklon k hypochondrii (kult zdraví);

- zážitky bez hlubšího hledání smyslu;

- identifikace s celebritami;

- strhávání pozornosti pouze na svoji osobu;

- krize identity a krize vztahů.

V těchto několika bodech je tak shrnuto, co esenciálně patří do pojmu kulturního narcismu, i to, co bývá jeho nejčastějším projevem (Lasch, 1980).

\section{Charakter kulturního narcismu}

Sociologové se pochopitelně ptají, kde má tato společenská dimenze narcistního chování svůj počátek. Lasch měl jako Američan pro genezi sociálního narcismu poměrně jednoduchou a logickou teorii. Připomněl na podkladě odkazu Maxe Webera, že po celou historii USA byl ideálním občanem ten, kdo se identifikoval s tzv. protestantskou etikou. Protestanská etika vycházela z kalvínské teologie předurčení - predestinace. Bílí lidé, kteří přicházeli z Anglie do Nového světa - budoucích Spojených států, byli vesměs věřící kalvinisté a vyznávali víru ve své předurčení pro posmrtnou spásu, ke které byli předem (úradkem Boha) určeni. Poznat své předurčení je však podle této teologické koncepce obtížné. Prakticky to jde pouze jediným, relativně jistým, způsobem, a to schopností žít mravně podle biblických morálních přikázání. Plnit v síle tzv. boží milosti řád dobrého života, vlitý do srdce předurčeného, dává věrícímu naději, že je předurčen pro nebe. Člověk této mravní kvality neschopný (lenoch, hlupák, závislý na neřestech atd.) pak může poznat svoji tzv. reprobaci, předurčení $\mathrm{k}$ věčnému zavržení.

I přesto, že se tato teistická víra pod vlivem osvícenství postupně transformovala do deismu či byla mnohde popřena ideologií vědeckého ateismu, protestantská morálka implicitně dále určovala občanský a společenský diskurs všech bílých Američanů. Spořádaný občan žil soustavně pro budoucnost své rodiny a své země, tvrdě pracoval, moudře investoval a pro své investice 
byl schopen se aktuálně uskromnit, a především podřídit svoji vůli a city (žádosti) rozumu. Byl to jakýsi self-made man. Je tedy pochopitelné, že takto ukázněně pracující občan si v době industriálního kapitalismu nahromadil mnoho majetku a USA se staly objektivně nejbohatší zemí západního světa. Tímto zbohatnutím - většinou z plodů vlastní práce - se však občanovy touhy začaly obracet $\mathrm{k}$ blahobytu jako $\mathrm{k}$ cíli. Postupně se důraz přenesl na čistě materiální blahobyt. Z původně chudého, houževnatého a skromného občana se stal blahobytný člověk - hédonista. Bohatá americká společnost takto učinila velký progres a současná společnost vypadá jako podsvětí minulosti (Lasch, 1980, s. 53).

Zbohatnutím tak došlo k zásadnímu kulturnímu přerodu kapitalismu. Americký a posléze i evropský občan již nejpozději od 70. let 20. století nechce být skromný self-made man, nýbrž se stylizuje jako happy hooker, který se pokouší dojmout ostatní svým image (Lasch, 1980, s. 64). Jeho opravdu žádoucím cílem se stává potěšení - rychlé a př́ijemné potěšení, novodobé probuzení hédonismu. S tímto obratem od výkonné pracovitosti v minulosti k současnému hédonismu, který se závratně rychle uskutečnil během prvních dvou poválečných generací, také souvisí odpor ke všemu starému jakožto zastaralému. Tento odpor má také své odezvy na filosofické, ideové rovině. Poválečný člověk, pohoršený hrůzami posledních velkých celospolečenských ideologií (komunismu a nacismu), se stává bytostí, která je existenciálně vyvržena ze všech vnějších jistot a vydána napospas obecnému nesmyslu světa. Filosofický existencialismus, jak ho v poválečné době prezentoval především J. P. Sartre, vyvrhl člověka do existenciální prázdnoty. Český filosof Radim Palouš tento ideový posun, respektive oproštění člověka od jakýchkoliv velkých idejí, ve zkratce vyjádřil takto: Subjektivita je zde pojata jako vysazenost člověka do cizoty světa. Svobodou člověka je projekce smyslu do nesmyslného univerza (Palouš, 1990, s. 94).

Pro tuto absenci velkých celospolečenských cílů se postmoderní člověk postupně uzavřel do sebe, ve své smrtelné konečnosti, zbavený vší metafyzické opory v náboženství (původním kalvínském teismu) či kategorických morálních imperativech (osvícenecký ideál autonomní morálky). Tato ztráta celkového smyslu života jde pak ruku v ruce s dalším fenoménem, působícím dnes problém především $\mathrm{v}$ oblasti vzdělávání a přístupu k práci, s lhostejností. Lhostejnost je apatie nového stylu (Lipovetsky, 1998, s. 51) pramenící z toho, že naše společnost neuznává žádnou prioritu, definitivní kodifikaci ani střed, 
nýbrž jen neustálý výběr z řetězce rovnocenných stimulací (Lipovetsky, 1998, s. 53). Tento nový druh apatie k poznávání nového není způsoben žádnou nouzí, ale naopak přebytkem neustále se střídajících podnětů, což nakonec způsobuje, že čím více odpovědnosti a informací nám systém dává, tím méně nám na nich záleží (Lipovetsky, 1998, s. 53).

Pro oblast vzdělávání a výchovy je důležité vědět, že radikální odklon postmoderního člověka od moderny a jejích hodnot způsobil během posledních dvou generací jakýsi druh nové negramotnosti. Nejedná se však o pouhou krizi znalostí či poruchy učení v oblasti vlastní kulturní historie a idejí, které byly opuštěny. Nová negramotnost zasahuje hlouběji, a to především do oblasti elementárních znalostí z exaktních věd. Jejich získání je totiž ze své podstaty náročné a je spojeno s požadavkem disciplíny, trpělivosti a houževnaté skromnosti při procesu učení. Velmi málo mladých lidí je však dnes ochotno obětovat svůj čas a vůli pro získání znalostí v oblastech, jako je matematika, přírodní vědy, znalost dalšího jazyka apod. Pokud se již v raném věku nenaučil člověk nutné míře disciplinovanosti, trpí často až patologickou neschopností soustředění se a nedostatkem hlubšího zájmu o vážná témata a otázky týkající se vzdělání a výchovy.

Pro výše uvedené fenomény a patologické projevy byl narcismus Americkou psychiatrickou společností (APA) uznán i jako oficiální psychická porucha osobnosti, a to již v roce 1980, tedy ve stejném roce, ve kterém se prof. Lasch objevil se svojí výše uvedenou knihou na stejné téma. Problémem však je, že i když byl narcismus uznán jakožto porucha osobnosti, narcismem narušení lidé zpravidla fungují v normálním životě zcela běžným způsobem. $Z$ tohoto pohledu je zajímavá kniha Narcismus - vnitřní žalář z roku 1999, ve které se terapeut Heinz Peter Röhr věnuje nejen otázce vzniku a průběhu choroby narcismu, ale nastiňuje i možnosti jejího překonávání u těchto lidí s hraničním stádiem narcistické poruchy pohybujících se v normálním životě. Narcismus zde popisuje na pohádkovém příběhu od bratří Grimmů Železná kamna (Röhr, 2008). Podobně také americká příručka pro diagnózu duševních chorob Diagnostic and statistical manual of mental disorders (DSM) zveřejnila, že narcismus se dá u běžně fungujících lidí určit, a to tak, že z devíti uvedených příznaků musí být pro diagnózu narcisty splněno alespoň pět: 
1) Přeceňuje vlastní důležitost, schopnosti a úspěchy a vyžaduje, aby je ostatní hodnotili stejně jako on.

2) Ve fantazii se zabývá nekonečnými vlastními úspěchy, mocí, krásou a podobně.

3) Je přesvědčen o vlastní výjimečnosti a jedinečnosti, takže jen výjimeční lidé ho mohou pochopit a jen s takovými se může stýkat.

4) Vyžaduje nepřiměřený obdiv ostatních.

5) Nárokuje si výjimečné zacházení nebo automatické plnění svých přání a představ.

6) Využívá druhých jen k dosahování vlastních cílů.

7) Není schopen rozeznat potřeby a city druhých.

8) Často závidí a bývá přesvědčen, že druzí závidí jemu.

9) Chová se arogantně a přezíravě (DSM, 2017).

Problém je však přesto ještě složitější. V roce 2010 bylo Asociací pro výzkum osobnosti diskutováno, jestli všechny tyto výše uvedené znaky nutně odpovídají pouze narcistické poruše (Schmeck et al., 2013). Většinu projevů této poruchy můžeme totiž pozorovat i u osobnosti antisociální, popřípadě obsesivní (Skodol, Bender, \& Morey, 2013). Většina badatelů, kteří působí v rámci Mezinárodní společnosti pro studium poruch osobnosti, se nakonec shodla na tom, že narcistická porucha osobnosti bude ponechána samostatně, a to se čtyřmi charakteristickými projevy, jako je patologická povaha, dále grandiózní, či naopak vulnerabilní fenotyp, expresivita, či naopak neschopnost expresivity ve vyjadřování a celková struktura osobnosti (Morey \& Stagner, 2012).

Mnoho souvisejících výzkumů, které korespondují s výše uvedenou typologií narcisty podle APA, se shoduje v tom, že narcismus je charakteristickým rysem osobnosti, který je měřitelný. Tato měřitelnost se pak také stala základem níže uvedených výzkumů mezi vysokoškolskými pedagogy v USA. Narcistickou poruchu osobnosti je totiž možno měřit metodami, které zjišt’ují přítomnost především těchto povahových rysů: arogance, sebestřednost, touha po pozornosti, vykořistování, šarm, lstivost, zlomyslnost, pohrdání, pomstychtivost, chlubivost, rozpačitost, grandiozita, rezervovanost, nepř́istupnost, nejistota, lhostejnost, úzkostnost, povýšenost, chladnost, agresivita, denní snění, plachost, sexuální inhibice a další (Paris, 2014). 


\section{Fenomény narcismu}

Z výše uvedeného je tedy zřejmé, že vlivem odklonu postmoderního člověka Západu od jeho moderní minulosti vznikl nový narcistní způsob života. Narcismus je tedy dnes sociální fenomén, jakkoliv býval původně diagnostikován pouze jako psychická patologie jednotlivců. Narcistický požadavek co nejmenších omezení a na druhé straně co největšího otevření prostoru pro ničím a nikým neohrožovanou svobodu se stává celospolečenským fenoménem dokonale personifikované společnosti (Lipovetsky, 2013). Tento celospolečenský fenomén je u lidí zřejmý již od raného dětství a jako první se s ním kromě rodičů setkávají především učitelé a vychovatelé ve svém pedagogickém působení. Pedagog je pak často nucen maximálně se přizpůsobit hédonistickým požadavkům žáků, z nichž se stávají klienti, kteří se chtějí ve škole cítit především příjemně.

Spolu s hlubokou přeměnou přístupu $\mathrm{k}$ výchově a ke vzdělávání se společenský narcismus projevil na prvním místě $\mathrm{v}$ proměně fungování rodiny. Podobně, jako byl opuštěn ideál jednotlivce ve smyslu výše uvedeného self-made man, dopadl i model tzv. tradiční rodiny. Proces odklonu od tradičního pojetí rodiny započal jistě již dříve v moderně, a to v souvislosti se vznikem industriální společnosti. Rodina, která v premoderně trávila společný čas práce i odpočinku většinou v zemědělské pospolitosti, se v industriální společnosti stala nebývale závislou na byrokratických institucích státu, jako jsou školství, zdravotnictví či instituce vykonávající státní dohled nad mnoha oblastmi soukromého života sekularizovaného občana. Rozličné společenské instituce jako by oslabily vnitřní rodinné vztahy a uvěznily je do své hierarchie. Na tomto tzv. principu biomoci pak byly dříve přirozené vazby převrstveny tzv. diktátem normality a byla jim vnucována konformita. Tento fenomén již v 70. letech minulého století zpracoval Michel Foucault a shrňme ho zde tímto jediným, avšak výstižným citátem z jeho jinak rozsáhlého díla:

Nová technologie, která nastupuje později, se obrací k množství lidí, ale nikoli jako k souhrnu jednotlivých těl, nýbrž tak, že naopak tvoří globální masu, na niž působí souborné procesy, jež jsou vlastní životu a jimiž jsou např́ílad narození, smrt, produkce, nemoc atd. Tedy po prvém zmocnění se těla, jež se děje individualizací, je zde druhé zmocnění se, jež není individualizující, nýbrž masifikující. (Foucault, 2005, s. 257)

Právě tyto pokusy o vytvoření homogenní masy, která často přijímá diktát normality „stádovitě“, se citelně projevují především na oslabení vnitřních 
rodinných vazeb. Současná malá, nukleární rodina, často neúplná, pouze biologická matka s jedním či dvěma dětmi, snadno podléhá diktátu konformity ve formě reklamy, módy a společenských trendů. Významný americký sociolog Daniel Bell, který zkoumal změny vzorců chování v americké společnosti, se k tomuto v knize Kulturní rozpory kapitalismu vyjádřil takto: „Postupně začala reklama ovlivňovat i základnější vzorce lidského chování: strukturu autority $\mathrm{v}$ rodině, společenskou roli dětí a mladých lidí jako samostatných spotřebitelů, vzorce etického chování a pojetí společenského úspěchu." (Bell, 1999, s. 78).

A právě zde se odhaluje narcismus jakožto přímý produkt novodobého happy hooker hédonismu. Přirozeným pojítkem mezi tímto hédonismem a narcismem je konzumní spotřeba, která je hlavním hybatelem konzumní společnosti. Je sice pravda, že symbióza narcismu a hédonismu je do značné míry závislá na konkrétní ekonomické situaci dané společnosti, nicméně i v chudších západních ekonomikách platí, že kulturní transformaci moderní společnosti vyvolal především nárůst masové spotřeby, tedy rozšíření zboží, dříve považovaného za luxusní, mezi střední a nižší vrstvy společnosti. Jde o proces, v jehož rámci je stále další a další zboží definováno jako nutná potřeba (Bell, 1999, s. 75). Současná rodina je tedy jako první sociální jednotka výchovy a vzdělávání prostředím, ve kterém kulturní narcismus nachází živnou půdu a pevně koření.

Kromě této krize rodiny je dalším významným fenoménem proměna vztahu postmoderního člověka k vlastní psychice, duševnosti. „Psychoanalytik mlčí, zemřel, a my všichni psychoanalyzujeme sami sebe v bludném a bezvýchodném kruhu. Don Juan zemřel a objevila se nová, mnohem znepokojivější postava: Narcis, okouzlený sám sebou ve své skrz naskrz průhledné komůrce." (Lipovetsky, 1998, s. 63). Takto v knize Éra prázdnoty definuje Lipovetsky totálně individualizovaného hédonistu, který dotváři kulturní narcismus tím, že svoji prázdnotu touží sdělovat prázdnotě sobě podobných. A protože díky explozi komunikačních technologií je možnost sdílení více nežli snadná, narcista sděluje svůj názor komukoliv, pouze pro své vlastní narcistní potěšení, tedy bez ambice cokoliv svým názorem změnit či vylepšit. V tomto narcistním hédonismu je základní hodnotou člověk, který je mírou všech věcí, pouze na něm záleží (Lipovetsky, 1998, s. 63). Toto výrazné nasměrování se na narcistní sebepozorování se pak často projevuje právě tím, s jakým úmyslem je využívána současná psychoterapie. Lidé postižení kulturním narcismem hojně tyto terapie navštěvují, avšak často nikoliv proto, 
aby analyzovali, a tak pochopili hlubinu svých problémů, které pak budou pod vedením terapeuta následně řešit. Základní intencí, proč takový člověk vyhledává psychoterapeuta, je často pouze to, aby se něco nového o sobě dozvěděl.

Jako další fenomén narcismu, související s předchozím, je možno uvést explicitní odhalování existenciální prázdnoty subjektu a uzavírání se před vnější společností tím, že narcista vyhledává anonymitu virtuálního světa na internetu, sociálních sítích, ve sdíleném on-line hraní her nebo se v reálném světě uzavírá pouze do zájmových skupin. $V$ nich je pak jeho narcismus akceptován a vzájemně sdílen, jak podrobně popsal sociolog Richard Sennett v práci The fall of public man. Zde rozvedl fakt, že veřejný prostor, ve kterém se lidé setkávají a řeší společně společenské problémy, prakticky vymizel, respektive byl nahrazen jakýmsi intimním sdělováním vzájemných pocitů. Současná zkušenost ze sociálních sítí potvrzuje, že nejčastější otázkou, kterou si lidé v kontaktu kladou, je, co cítí či jak se cítí (Sennett, 1977). Př́íjemnost prožitku či pouhý dobrý pocit se tak pro narcistu stává jediným měřítkem reality.

Nejviditelnějším fenoménem narcismu, který působí ve společnosti i socio-ekonomické problémy, je pak lhostejnost k práci jakožto nástroji životního rozvoje. Po ukončení povinného vzdělání - education, které muselo být pro narcistu př́jemné a cool, se fenomén narcistní lhostejnosti u současné druhé generace přenáší i do prostoru zaměstnání, do prostoru work. Práce v zaměstnání je narcistou uchopena především na instrumentální rovině. Jde o nutné zlo, ve kterém je třeba co nejsnadněji a nejrychleji vydělat peníze, aby byla získána dostatečná ekonomická základna pro prožívání volnočasových narcistních vztahů. Práce je narcistou pojímána jakožto tíživá povinnost, avšak utilitárně nutná pro prožívání volného času. Zaměstnání je nutné zlo týdne, připravující pro opravdový život o víkendu. Pro snesitelnost tohoto nepř́ijemného období pracovního týdne roste $\mathrm{v}$ atmosféře kulturního narcismu tlak na maximální zpř́ijemnění zaměstnání. Rostou požadavky na volnou pracovní dobu či snaha zmírnit neoblomnost organizace, nahradit jednotné a př́ísné pracovní řády modely s pružným uspořádáním a dát přednost komunikaci před donucováním (Lipovetsky, 1998, s. 32). Např́íklad podle velmi známého a často komentovaného výzkumu dvojice Simon Winlow a Steve Hall, s názvem Living for the weekend - Youth identities in northeast England, uveřejněného v SAGE journals v roce 2009, mladí respondenti necítili žádný vztah $\mathrm{k}$ výtvorům své práce. Jediným ziskem z jejich pracovní činnosti byly 
peníze, kterými chtěli svůj reálný život dotovat. Tento život pak prožívali právě pouze o víkendech. Podobně na základě svých výzkumných projektů popisuje kulturní narcismus také Simon Gottschalk. Ten již v roce 2009 ve vědeckém časopise Journal of Consumer Culture analyzoval v článku s názvem Hypermodern consumption and megalomania: Superlatives in commercials jakési hypermoderní trendy vedoucí k narcismu, totiž zrychlení, sledování, viditelnost a nadbytek a jejich transformaci v ekonomické, kulturní a politické sféře, projevující se v pasivním zájmu o práci v zaměstnání (Gottschalk, 2009). Podobně jako on se vyjadřuje i G. Lipovetsky o narcistní mentalitě jako o hypermodernitě (Lipovetsky, 2013), která dotahuje ideály moderny ad absurdum, kdy se na vrcholu společenské pustiny tyčí svrchovaný, informovaný a svobodný člověk, obezřetně spravující vlastní život (Lipovetsky, 1998, s. 16).

Individualizace hypermoderního člověka, narcistně zahleděného pouze do sebe, pak převládá nad všemi ostatními sociálními aspekty, především nad zájmem o práci a o veřejný prostor. Tím pak vzniká jakési nulové sociálno (Lipovetsky, 1998, s. 19), což je označováno jako druhá fáze konzumní společnosti (Lipovetsky, 1998, s. 26). Jedním z nejviditelnějších znaků takovéhoto jednání je na jedné straně přehnaná aktivita vůči své osobě, ale pasivita a lhostejnost vůči okolnímu světu a jeho dění. Individualizovaný jedinec se stal pasivním pozorovatelem veřejného dění, kterému pouze přihlíží, často bez vlastního názoru, dobře bavený, neodpovědný jinému nežli svému časoprostoru, dokonale personalizovaný, odsouzený k narcistické samoobslužnosti (Lipovetsky, 1998, s. 52).

\section{Realizované výzkumy narcismu}

S výše popsanými fenomény kulturního narcismu, který došel až daleko za hranice Freudem tolerovaného přirozeného narcismu, se potýkají především ti, kteří nesou odpovědnost za výchovu a vzdělání, bez ohledu na stupeň vzdělávací soustavy. Tito se pak často ve svém učitelském či vychovatelském postavení pedagogického pracovníka ocitají ve stavu jisté bezradnosti:

Co říká učitel, přestalo být posvátné, zevšednělo to na úroveň toho, co říkají sdělovací prostředky, a ze školství se stalo soukolí, jehož výkonnost maří apatie vznikající z nesoustředěnosti a nepokryté skepse vůči vědění. (Lipovetsky, 1998, s. 61-62) 
Toto však způsobuje závažné poruchy učení a onu výše uvedenou novou negramotnost u posledních dvou generací. Je tedy na místě, aby v rámci pedagogické orientace bylo ve stejnojmenném odborném časopise poukázáno, kde a jakými metodami je v oblasti vzdělávání narcismus zkoumán. Otázka, která nás tedy nyní bude zajímat, je, jak se narcistní tendence u současné generace žáků a studentů konkrétně projevují a jakými metodami je lze relevantně měřit. Možnost rámcového zjištění úrovně narcismu v konkrétních školních kolektivech se jeví důležitou především pro pedagoga, který se chce v tomto prostředí zasaženém narcistní poruchou lépe orientovat.

Problematikou měrení úrovně narcismu ve školním kolektivu se již od roku 2003 zabývá několik výzkumných týmů v USA, které vede psycholog doktor W. Keith Campbell, profesor univerzity v Georgii na katedře psychologie. Tento profesor se mezi lety 2002-2008 se svými kolegy (Rudich, Sedikides, Foster, Goodie a další) věnoval zjištování míry narcismu u studentů středních a vysokých škol. Jejich výzkumu se tedy především účastnili studenti v rámci svých studijních povinností.

Campbellova definice současného narcismu se od výše uvedených nijak neliší. Míra narcismu je zde zjištována skrze úhel pohledu na vlastní osobnost u samotného respondenta. Respondent-narcista se totiž v určité měřitelné míře potýká s pocitem své výjimečnosti, který je důsledkem jeho přehnané představy o své atraktivitě a exkluzivitě. $V$ návaznosti na předchozí výzkumy shrnují tento aspekt Campbell a kolegové (2004, s. 298) takto: K těmto myšlenkovým pochodům docházejí narcisté skrze samoregulační strategie, a to zejména pomocí intrapsychických a interpersonálních strategií, které jim napomáhají k udržení jejich představ o sobě. Po stránce intrapsychických procesů si narcisté svůj život představují jako skvělý a své úspěchy připisují svým téměř nadlidským dovednostem. Strategii interpersonálních procesů využívají k postavení sama sebe do středu zájmu a pozornosti. Narcisté projevují zájem o vztahy s vysoce postavenými a vlivnými lidmi. Lze říci, že hlavním důvodem pro toto jednání je vidina vlastního úspěchu. Jelikož je velmi těžké $v$ narcistické povaze přiznat vlastní chybu, narcisté velmi často svalují své neúspěchy na lidi či věci v jejich okolí. Svým jednáním se také mohou dostávat do velmi nepř́ijemných situací, a to zejména pokud přeceňují své dovednosti. Narcisté však přesto velmi často př́liš věří pouze ve svou osobu, a proto se vystavují riskantním situacím. 
Výzkum míry sebevědomí u současné mladé generace proto profesoři Campbell, Goodie a Forster shrnuli pod název Narcissism, confidence, and risk attitude - Narcismus, sebedůvěra, ochota riskovat a pod tímto názvem také vyšla studie v Journal of Behavioral Decision Making v roce 2004. Své hodnocení míry narcismu výše uvedení autoři vložili do škály v polohách mezi non-narcissists a narcissists.

Prvního z těchto tří výzkumů se účastnilo 104 respondentů z řad studentů univerzity v Georgii ve věku okolo 18 let. Vyplňovali ve třech počítačových učebnách elektronický dotazník, který byl součástí jejich studijních povinností v aktuálním studijním kurzu. Dotazník byl složen ze dvojic otázek, z nichž první se zaměřovala na znalosti, knowledge question, a druhá na hodnocení sebejistoty v odpovědi na první vědomostní otázku, confidence assessment. Na uvedeném obrázku z publikace výzkumu je př́klad jedné ze 150 podobných vědomostních otázek, které byly náhodně vybrány z cca 300 otázek všeobecného rozhledu:

Kdo byl prvním vládcem ve Svaté říši římské? Možné odpovědi: a) Charlemagne nebo b) Zeus. Po zodpovězení dané otázky následuje otázka doplňující: Jestliže jsi odpověděl a) Charlemagne, jak moc jsi si svou odpovědí jistý? Respondent pak zaškrtl jednu z možností a-g, vyjadřujících procenty kategorii důvěry ve správnost své odpovědi: (a) 50-52\%; (b) 53-60\%; (c) 61-70\%; (d) 71-80\%; (e) 81-90\%; (f) 91-97\%; (g) 98-100 \%. Závěr tohoto výzkumu ukázal, že respondenti si většinou věřili více, nežli měli faktických znalostí. Tím se potvrdila hypotéza Campbelova týmu, že narcisté si věří o mnoho více nežli ne-narcisté, ačkoliv odpovědi narcistů na úrovni faktů jsou často zcela nesprávné. Tímto výzkumem tedy bylo demonstrováno, že míra narcismu je přímo úměrná s přemírou sebejistoty.

Druhý z této trojice výzkumů autoři zaměřili na otázku, do jaké míry je narcista schopen riskovat. Studie se účastnilo 97 respondentů, podobných jako u studie první. Metoda poznání míry ochoty riskovat spočívala ve strategii, že na 101 vědomostních otázek dostali respondenti možnost odpověd' ještě změnit či vsadit na jinou odpověd. Závěr studie ukázal, že narcisté jsou schopni více riskovat a hazardovat - více sázet a tipovat.

Třetí z těchto studií se účastnilo nejvíce respondentů, totiž 607. Studie byla zaměřena na vztah mezi sebedůvěrou, self-beliefs a sebe-prezentováním v riskantních situacích. Šlo o ověření hypotézy, že narcista ve svém 
přehnaném sebehodnocení a pocitu výjimečnosti přináší do riskantní situace tolik pozitivní víry $\mathrm{v}$ sebe, že mu to nakonec často zvýší i šanci na úspěch. A pokud narcista $v$ rovině faktů neuspěje, zda si svoji víru v sebe udrží dál i tváří v tvář objektivnímu selhání. Campbellův tým zjistil, že v takovém př́ípadě narcisticky orientovaní jedinci využívají tzv. top-down strategii. Při ní jakoby sami sobě v duchu opakují, že jsou dobří a skvělí, a tím pádem nemohou být v úkolu neúspěšní. Díky této vnitřní narcistní strategii zůstávají hrdí a sebevědomí i v případech, kdy jsou jejich výkony na faktické úrovni nízké či vyloženě špatné.

V rámci studie byly respondentům, kteří plnili rozličné vědomostní úkoly, položeny tři otázky (jedna před úkolem a dvě po něm):

a) Jakou úspěšnost respondent očekává před provedením?

b) Jak respondent hodnotí svoji úspěšnost po provedeném úkolu?

c) Jak si respondent myslí, že bude úspěšný v budoucnosti při stejném či podobném zadání?

Hodnocení jednotlivých otázek bylo vyjádřeno škálou od 1 (nejméně) do 10 (nejvíce). Výsledkem této studie pak bylo zjištění, že narcisté se nejen nekriticky domnívají, že budou jistě úspěšní v následujícím úkolu, ale že byli (často bez ohledu na skutečný výsledek) úspěšní a v budoucnosti budou ještě mnohem úspěšnější. Takto byla potvrzena původní hypotéza, že narcisté považují často zcela v rozporu s vnější realitou své schopnosti za skvělé, a to i v případech, kdy je opak pravdou. Jejich budoucí očekávání v oblasti výkonnosti byla navíc silně ovlivněna jejich nafouknutými odhady výkonnosti, provedenými před započetím úkolu (Campbell et al., 2004).

V závěrečném shrnutí těchto tří publikovaných výzkumů bylo deklarováno, že narcisté jsou v př́padě vlastního rozhodování ovlivněni jak př́lišnou sebejistotou, tak touhou riskovat, zvláště tam, kde byl úspěch závislý nikoliv primárně na znalosti či dovednosti, ale na risku a sázce. A i když díky této své riskantnosti ztráceli velký počet bodů, přesto posuzovali své výkony dle svého očekávání, a nikoliv podle vnější reality. Dále bylo ukázáno, že narcistní jedinec může díky svému nekritickému optimismu, sebelásce a absenci strachu z neúspěchu a deprese v tomto svém emočním rozpoložení čerpat určité emocionální benefity. Autoři výzkumů se tak připojili k výsledkům starších př́padových studií na téma narcismu a potvrdili hypotézu, že narcisté jsou ve skutečnosti obecně štastnější než ostatní, mají výšší sebeúctu a méně 
depresí a úzkostí (Watson \& Biderman, 1994). Poněkud pozměněný tým prof. Campbella ve složení Campbell, Rudich a Sedikides publikoval v časopise Personality and Social Psychology Bulletin již v roce 2002 další ze svých zajímavých výzkumů pod názvem Narcissism, self-esteem, and the positivity of self-views: Two portraits of self-love, tedy Narcismus, sebe-úcta a pozitivní sebe-pohled: dva pohledy na sebe-lásku (Campbell, Rudich, \& Sedikides, 2002).

Posledním zajímavým výzkumem, tentokrát v oblasti narcismu na sociálních sítích, se zabýval prof. Campbell se svými kolegy. Tento jejich výzkum byl zveřejněn v roce 2008 pod názvem Narcissism and Social networking web sites (Buffardi \& Campbell, 2008). Výzkum ukazuje, že narcisté na sociálních sítích, především na Facebooku, vykazují mnohem větší sebevědomí, než jaké mají ve skutečnosti.

Tyto výzkumy ukazují, že narcisté mívají sice v reálném světě nižší sebevědomí, zato jsou však v on-line aktivitách mnohem kreativnější a dokáží pro svoji sebeprezentaci a vylepšení on-line image udělat cokoliv. Typickým rysem narcistického chování tak je zveličování informací ohledně vlastní osoby a chlubení se.

Některé výše uvedené výzkumy na téma kulturního narcismu pak prof. Campbell spolu se svým kolegou psychologem ze San Diega Jeanem M. Twenge publikoval v monografii The narcism epidemic, která sice již nevykazuje znaky prrísně vědecké práce, ale shrnuje a analyzuje výsledky těchto zajímavých empirických výzkumů, které vypovídají o stavu narcismu v západní společnosti.

Pochopení epidemie narcismu je důležité, protože má dlouhodobé konsekvence a pro společnost je destruktivní. Zaměření americké kultury na sebe-obdiv způsobilo odklon od reality ke grandióznímu fantazijnímu světu s falešnými [v originále phony; pozn. aut.] boháči, falešnou krásou, falešnými sportovci, falešnými celebritami, falešnými geniálními studenty, falešnou ekonomikou, $\mathrm{s}$ falešným přístupem rodičů $\mathrm{k}$ dětem, $\mathrm{k}$ falešným přátelům. Celá tato falešnost by mohla být prožívána př́íjemně, ale bohužel realita vždy vyhrává. Kolaps hypoték a následná finanční krize jsou jen jednou demonstrací toho, že všechny nafouknuté touhy nakonec spadnou zpět na zem. (Twenge \& Campbell, 2009, s. 6)

Autoři v knize následně popisují trend kulturního narcismu, který je stále na vzestupu a zasahuje hodnoty stále většího počtu lidí, jež jsou do této pasti sociálního trendu lapeni: 
- První oblastí, kde se tento trend narcismu podle autorů stále více projevuje, je oblast výchovy. Rodiče stále méně vštěpují svým dětem tradiční západní hodnoty, jako je svoboda, rovnost a tvrdá práce. Namísto toho v rodinné výchově roste „kult dítěte“, které chce a má být obdivováno a má být vychováváno ve víře, že pro svůj seberozvoj může cokoli. Rodiče, kteř́ jsou sami postiženi narcismem, takto přenášejí narcismus na další generaci.

- Druhou oblastí, kde se narcismus projevuje a působí destrukci, je oblast nekritického obdivu k celebritám. Novodobé celebrity si často nevysloužily svou slávu tvrdým bojem a houževnatou soustavnou prací. Dnešními celebritami jsou spíše „udělané celebrity“, jako herci, mediálně zajímavé a často excentrické osoby, které Twenge nazývá superspreaders. Ti však kolem sebe často šírí pouze nadřazenost a domýšlivost. Jedním z klasických př́kladů, jak tyto celebrity ovlivňují život svých narcistických obdivovatelů, je to, že mezi mladými roste móda najímat si své paparazzi, aby je sledovali při jejich soukromém životě. Tyto záběry ze soukromí jsou pak narcistně sdíleny na sociálních sítích a každý se pak alespoň v okruhu svých známých může cítit celebritou. Dále u těchto lidí dochází k narůstání touhy po luxusu, na který má nakonec každý obdivovatel právo, stejně jako má právo chovat se jen podle svých představ, tak jako obdivované celebrity.

- Třetí oblastí, ve které je narcismus stále viditelnější, je trend, který proniká do všech, i vědeckých, oblastí a který je v podtextu často užívané fráze You have to be hot! - Musíte být žhaví! Jedná se o určitou společenskou obsesi kultem tělesné krásy. Do extrémů je dovedena např́klad nadužíváním plastické chirurgie, fitness salónů atd. Takto se rodí „narcista-metrosexuál“, který chce být vždy luxusní, krásný, oblečený ve značkových oblecích podle poslední módy, zkrátka stále in, nikoliv out to day.

Je zřejmé, že výše uvedené trendy jsou úzce propojené a jakoby zacyklené s otázkou zvyšování konzumní spotřeby, a tedy i opětovného udržování ekonomiky. Autoři také upozorňují, že ačkoliv se jejich výzkumy týkají pouze USA, stejný trend je nastartován či již dlouhodobě běží všude tam, kde je ekonomicky vyspělý svět přítomen, dokonce i v Číně, která byla donedávna spíše uzavřenou kulturou, zcela mimo okruh idejí západního světa. 


\section{Závěr jakožto nový začátek}

V oblasti výzkumů stran kulturního narcismu musíme rychle přejít k závěru, protože již není o čem dále psát. Je faktem, že v celém euroatlantickém prostoru se této tématice nevěnuje mnoho vědců či odborných týmů, a pokud ano, pak pouze na lokální úrovni. Následující výčet odborných studií není samozřejmě úplný, protože v každé z evropských zemí jistě existuje na lokální úrovni ještě nějaký další text o kulturním narcismu. Avšak na mezinárodních odborných fórech či v mezinárodních odborných časopisech stále ještě není výzkum narcismu frekventovaným tématem. Co se týká západní Evropy, tam jsou zatím zveřejněny pouze nemnohé př́ležitostné studie či př́ípadové studie, jako je např́klad Severe personality disorders, vydaná v Cambridge University Press v roce 2007 . Z větších publikací vyšly zatím pouze dvě monografie, od Arnolda Rothsteina The narcissistic pursuit of perfection $v$ roce 2012 a od Josepha H. Berke Why I hate you and you hate me: The interplay of envy, greed, jealousy, and narcissism in everyday life v Anglii v Karnac London v roce 2012. Co se týče výzkumů na toto téma v Česku, jedinými zástupci jsou odborníci okolo českého sociologa Františka Bartoše, nutné je zmínit především jeho odborný článek v Sociologickém časopise z roku 2010 s názvem Širší souvislosti neklinického narcismu: profesní život, komunikace a sebekontrola. Závěry jejich výzkumů lze shrnout do několika zajímavých zjištění: v ČR je narcistické chování fenoménem především svobodných a bezdětných lidí ve věku do 29 let, kteří jsou politicky spíše pravicově orientovaní a žijí převážně v městských aglomeracích nad 5000 obyvatel. Intimitu tito narcisté sdílí paradoxně více s kolegy nežli se svými sexuálními partnery (Soudková \& Bartoš, 2012). Avšak toto sdílení osobního intimního prostoru s kolegy má za účel spíše narcistně okouzlit a dokázat svoji privilegovanost.

Další menší prací, která je vytvořena českým autorem, je kniha Narcismus psychologická hrozba budoucnosti od Jiř́ího Adamce z roku 2008. V roce 2005 pak konceptu narcismu v psychoanalýze věnovala jedno ze svých čísel Revue, Česká společnost pro psychoanalytickou psychoterapii, člen Evropské federace pro psychoanalytickou psychoterapii.

Dále jsme $\mathrm{v}$ češtině již odkázáni pouze na několik překladů zahraničních prací. V roce 2008 vyšla výše uvedená monografie H. P. Röhra Narcismus vnitřní žalářr, která však představuje narcismus více méně pouze z psychologického, a nikoliv kulturního hlediska. Ze stejného psychoanalytického a psychoterapeutického hlediska pak lze problém narcismu ještě nahlédnout 
v překladu knihy Kathrin Asperové Opuštěnost a sebeodcizení z roku 2009. Toto jsou prakticky všechny větší práce zabývající se narcismem z teoretického hlediska, avšak výzkumy či alespoň překlady výše uvedených relevantních mezinárodních výzkumů zcela chybějí.

Tento příspěvek je proto zároveň i určitou výzvou k novému začátku, totiž ke spojení sil ke společným podobným aktivitám na poli pedagogických výzkumů, nejlépe (nikoliv však nutně) uvnitř České asociace pedagogického výzkumu či ad casum sestaveného týmu, sdruženého okolo přípravy nějakého výzkumného projektu. Vždyt' k plánování a koordinaci pro společnost potřebných pedagogických výzkumů vybízel i tento časopis již v roce 2010 (srov. Janík, 2010). Výše představené výzkumy Campbellova týmu mohou být v tomto především metodologickou inspirací.

\section{Poděkování}

Poděkování autora patří anonymním recenzentům za podnětné poznámky, které vedly k určitému doplnění a zpřesnění tohoto textu.

\section{Literatura}

Adamec, J. (2008). Narcismus: psychologická hrozba budoucnosti. Brno: Filosofický seminár.

Asper, K. (2009). Opuštěnost a sebeodcizení: nové př́stupy k terapii narcistické poruchy osobnosti. Praha: Portál.

Bartoš, F. (2010). Širší souvislosti neklinického narcismu: profesní život, komunikace a sebekontrola. Sociologický časopis, 46(5), 745-770.

Bell, D. (1999). Kulturní rozpory kapitalismu. Praha: Sociologické nakladatelství.

Berke, J. H. (2012). Why I hate you and you hate me: The interplay of envy, greed, jealousy, and narcissism in everyday life. London: Karnac Books. Dostupné z http://site.ebrary.com/lib/ natl/Doc?id=10602500

Buffardi, L. E., \& Campbell, W. K. (2008). Narcissism and social networking web sites. Personality and social psychology bulletin, 34(10), 1303-1314.

Campbell, W. K., Rudich, E. A., \& Sedikides, C. (2002). Narcissism, self-esteem, and the positivity of self-views: Two portraits of self-love. Personality and Social Psychology Bulletin, 28(3), 358-368.

Campbell, W. K., Goodie, A. S., \& Foster, J. D. (2004). Narcissism, confidence, and risk attitude. Journal of Behavioral Decision Making, 17(4), 297-311.

Foucault, M. (2005). Je třeba bránit společnost: kurs na Collège de France 1975-1976. Praha: Filosofia.

Freud, S. (1997). Totem a tabu: o podobnostech v duševním životě divocha a neurotika. Praha: Psychoanalytické nakladatelství.

Fromm, E. (1996). Lidské srdce. Praha: Nakladatelství Josefa Šimona. 
Gottschalk, S. (2009). Hypermodern consumption and megalomania: Superlatives in commercials. Journal of Consumer Culture, 9(3), 307-327.

Janík, T. (2010). Stav a výhledy českého pedagogického výzkumu. Pedagogická orientace, 20(2), $5-22$.

Lasch, C. (1980). The culture of narcissism: American life in an age of diminishing expectations. New York: Warner Books.

Lasch, C. (2016). Kultura narcismu: americký život ve věku snižujících se očekávání. Praha: Triton. Lipovetsky, G. (1998). Éra prázdnoty: úvahy o současném individualismu. Praha: Prostor.

Lipovetsky, G., \& Charles, S. (2013). Hypermoderní doba: od požitku k úzkosti. Praha: Prostor.

Morey L. C., \& Stagner, B. H. (2012). Narcissistic pathology as core personality dysfunction: Comparing the DSM-IV and the DSM-5 proposal for narcissistic personality disorder. Journal of Clinical Psychology, 68(8), 908-921.

Palouš, R. (1990). Světověk neboli hypotéza o konci novověku, ba o konci celého eurověku a o počátku světověku. Praha: Vyšehrad.

Paris, J. (2014). Modernity and narcissistic personality disorder. Personality Disorders: Theory, Research, and Treatment. 5(2), 220-226.

Rothstein, A. (1999). The narcissistic pursuit of perfection. London: Karnac Books. Dostupné z http://site.ebrary.com/lib/natl/Doc?id=10989910

Röhr, H.-P. (2008). Narcismus - vnitřní žalář: vznik poruchy, průběh a možnosti jejího překonání. Praha: Portál.

Sennett, R. (1997). The fall of public man. Cambridge: Cambridge University Press.

Schmeck, K., Schlüter-Müller, S., \& Foelsch, P. A., \& Doering, S. (2013). The role of identity in the DSM-5 classification of personality disorders. Child \& Adolescence Psychiatry \& Mental Health, 27(7), 1-11.

Skodol, A. E, Bender, D. S., \& Morey, L. C. (2013). Narcissistic personality disorder in DSM 5. Personality Disorders: Theory, Research, and Treatment, 5(3), 323-333.

Soudková, Š., \& Bartoš, F. (2012). Narcismus: skrytá dimenze soudobé společnosti. Praha: Národohospodářský ústav Josefa Hlávky.

Twenge, J. M., \& Campbell, W. K. (2009). The narcism epidemic. New York: Simon and Schuster.

Watson, P. J., \& Biderman, M. D. (1994). Narcissistic traits scale: Validity evidence and sex differences in narcissism. Personality and Individual Differences, 16(3), 501-504.

Wolfe, T. (1976). The me decade and the third great awakening. New York Magazine, 23, 26-40.

\section{Autor}

PaedDr. ICLic. Michal Podzimek, Ph.D., Th.D., Technická univerzita v Liberci,

Fakulta př́rodovědně-humanitní a pedagogická, Katedra filosofie, Komenského 314/2,

46001 Liberec, e-mail: michal.podzimek@tul.cz 


\section{Narcissism in education}

Abstract: As a result of the process of individualization, postmodern society has witnessed a significant shift in values. The traditional concept of education seems to be very problematic. The school becomes one of the most important social institutions in which students spend their time in the position of a special client who is to be satisfied in his or her needs. That kind of relationship promotes a wave of narcissism that deforms the attitude to external world. Selected studies of American provenance propose a pedagogical perspective on narcissistic phenomenon as a new trend in society. Cultural narcissism is part of the current transformation of Western society that may become a global phenomenon in the future. The paper tries to promote further research that is very needed in Europe level.

Keywords: narcissism, individualism, pathology, learning disorder, pedagogical research

ČŠI (2018). Rozvoj př́rodovědné gramotnosti na základních a středních školách ve školním roce 2016/2017: tematická zpráva. Praha: ČŠI.

Cílem tematického šetření, jehož výsledky představuje tato zpráva, bylo s využitím nástrojů nově vyvinutých v rámci projektu Národní systém inspekčního hodnocení vzdělávací soustavy v České republice (NIQES) posoudit podmínky, průběh a dosaženou úroveň vybraných aspektů př́rodovědné gramotnosti na 2 . stupni základních škol, resp. nižším stupni víceletých gymnázií, a na středních školách s maturitními obory, identifikovat silné a slabé stránky rozvoje uvedené gramotnosti z celkového pohledu a položit tak základ pro porovnání rozvoje gramotnosti v dalším cyklu. Souvisejícím cílem tematického šetření byla také formulace doporučení pro další podporu školám při rozvíjení př́rodovědné gramotnosti u žáků.

ČŠI (2018). Analýza zahraničních systémů hodnocení klíčových kompetencí a systémů hodnocení netestovatelných dovedností se souborem doporučení pro školní hodnocení klíčových kompetencí RVP ZV a externí hodnocení školní podpory rozvíjení klíčových kompetencí RVP ZV. Praha: ČŠI.

Česká školní inspekce zveřejňuje Analýzu zahraničních systémů hodnocení klíčových kompetencí a systémů hodnocení netestovatelných dovedností se souborem doporučení pro školní hodnocení klíčových kompetencí RVP ZV a externí hodnocení školní podpory rozvíjení klíčových kompetencí RVP ZV. Dokument byl vytvořen v rámci realizace individuálního projektu systémového Komplexní systém hodnocení. 